\title{
Considering evolutionary processes in adaptive forestry
}

\author{
François Lefèvre • Thomas Boivin • Aurore Bontemps • François Courbet • \\ Hendrik Davi • Marion Durand-Gillmann • Bruno Fady • Julie Gauzere • \\ Cindy Gidoin • Marie-Joe Karam • Hadrien Lalagüe • \\ Sylvie Oddou-Muratorio $\cdot$ Christian Pichot
}

Received: 16 November 2012 / Accepted: 7 February 2013 / Published online: 8 March 2013

(C) The Author(s) 2013. This article is published with open access at Springerlink.com

\begin{abstract}
- Context Managing forests under climate change requires adaptation. The adaptive capacity of forest tree populations is huge but not limitless. Integrating evolutionary considerations into adaptive forestry practice will enhance the capacity of managed forests to respond to climate-driven changes.

- Aims Focusing on natural regeneration systems, we propose a general framework that can be used in various and complex local situations by forest managers, in combination with their own expertise, to integrate evolutionary considerations into decision making for the emergence of an evolution-oriented forestry.

- Methods We develop a simple process-based analytical grid, using few processes and parameters, to analyse the impact of forestry practice on the evolution and evolvability of tree populations.

- Results We review qualitative and, whenever possible, quantitative expectations on the intensity of evolutionary drivers in forest trees. Then, we review the effects of actual
\end{abstract}

Handling Editor: Erwin Dreyer

Contribution of the co-authors FL coordinated the review and wrote the text. All co-authors contributed to the revisions of preliminary drafts. In addition, more specific contributions were as follows:

Part 2: AB, BF, JG, SOM, CP

Part 3: FC, HD, BF, SOM, CP

Part 4: MJK, HL

Box 1: TB, MDG, CG

Box 2: FC, CP

F. Lefèvre $(\varangle) \cdot$ T. Boivin $\cdot$ A. Bontemps $\cdot$ F. Courbet $\cdot$ H. Davi $\cdot$

M. Durand-Gillmann $\cdot$ B. Fady $\cdot$ J. Gauzere $\cdot$ C. Gidoin •

M.-J. Karam $\cdot$ H. Lalagüe $\cdot$ S. Oddou-Muratorio $\cdot$ C. Pichot

INRA, UR629 Ecologie des Forêts Méditerranéennes, URFM,

Domaine Saint Paul, Site Agroparc, 84914 Avignon Cedex 9,

France

e-mail: francois.lefevre@avignon.inra.fr and potential forestry practice on the evolutionary processes. We illustrate the complexity of interactions in two study cases: the evolutionary consequences for forest trees of biotic interactions and of highly heterogeneous environment.

- Conclusion Evolution-oriented forestry may contribute adapting forests to climate change. It requires combining short-term and long-term objectives. We propose future lines of research and experimentation.

Keywords Genetic resources - Silviculture - Adaptation · Climate change $\cdot$ Evolution-oriented forest management

\section{Introduction}

Ecosystem functioning depends on the adaptation of living organisms to their physicochemical environment. In particular, the maladaptation of trees to local conditions can provoke ecosystem dysfunctions such as forest dieback or failure of regeneration, and it can also affect biotic interactions between trees and associated species. Multi-site common-garden experiments, which allow modelling the reaction norm of current tree populations to climatic parameters, suggest that climate change will lead to a high risk of maladaptation of tree species, at least in some parts of the current distribution range (Savolainen et al. 2007; St Clair and Howe 2007). To maintain forest services under climate change, tree stands will have to respond within one to ten generations to (1) more frequent and more intense extreme climatic events, (2) changing mean climatic parameters and (3) other related changes such as parasite outbreaks (IPCC 2007). Consequently, ecological services of the forests will depend on the intensity and velocity of the evolution of tree populations in response to climate change (Rehfeldt et al. 2001). Thus, adaptation should be considered in a dynamic perspective, as a bouquet of evolutionary processes that 
change populations and communities to fit their environment. Among these processes, genetic adaptation, i.e. genetic change of a population responding to selection, can be rapid and contribute to the ecological success of species facing climate change including forest trees (Aitken et al. 2008; Hoffmann and Sgrò 2011). A recent review stressed the high potential of evolutionary response to climate change in trees (Alberto et al. 2013). However, evidence of lack of adaptation does also exist, e.g. niche limits and empty niches, including for tree species that have large population size and produce huge quantities of seeds (Bradshaw 1991).

During the last century, foresters have succeeded in adapting forest genetic resources to bioclimatic conditions very different from their native range, obtaining good survival, growth and reproduction in the new environments. Emblematic examples are the worldwide transfer of Pinus radiata (Yan et al. 2006) and the south to north translocation of Picea abies (Skrøppa et al. 2010). This adaptation was achieved in very few generations of trees, and it proceeds from plasticity and/or evolution. For each adaptive trait, the phenotypic plasticity and the capacity of evolution depend on the genetic content and the environment of the population, which can both evolve (Pigliucci 2008). Within each population, genetic changes of mean trait value, plasticity and evolvability result from the combination of random and selectively oriented processes that can be affected by forestry practice. Whether immediate response to selection can hamper future evolutions, e.g. due to erosion of the genetic diversity, remains an open question. Evidence from breeding experience shows that the genetic responsiveness of populations submitted to continuous selection can be maintained through time for some traits: Evolvability was maintained over more than 100 generations of selection for protein and oil content in the Illinois maize breeding population (Moose et al. 2004). No such long-term empirical evidence is available for trees. However, local adaptation that commonly emerged in most tree species over the course of post-glacial recolonisation provides another illustration of achieved evolution (Savolainen et al. 2007). Noticeably, this local adaptation did not completely erode within-population genetic variation of adaptive traits (Mimura and Aitken 2007; Alberto et al. 2013). The long-term maintenance of evolvability also depends on the genetic architecture of the traits under selection, and in the case of polygenic inheritance, Kremer and Le Corre (2012) showed that evolutionary changes first result from the selection of the fittest combinations of gene alleles before it reduces the allelic diversity at individual gene loci.

However, adaptation is not limitless. Futuyma (2010) reviewed the factors that can limit adaptation from the short term to the phylogenic time scale. Focusing on an ecological rather than geological time scale, we can retain here seven constraints to evolutionary changes. Firstly, developmental constraints result from functional interactions among traits involved in the elaboration of the performance. We use here 'performance' as a generic term, referring either to fitness components in an ecological perception or to forestry objectives like wood quantity or quality in an agronomic perspective, or to any combination of these traits. Secondly, genetic constraints result from the genetic architecture of traits, with complex epistatic interactions between several genes on one trait or pleiotropic effects of one single gene on several traits. Actually, forestry practices have little (but not null) impact on these first two limiting factors. Then, Futuyma (2010) identified four limiting factors of adaptation on which forestry practice may have direct or indirect impact: lack of genetic diversity, demographic stochasticity (counter-acting directional selection), random genetic drift and asymmetric gene flow (e.g. at niche limits). In addition to these, Kuparinen et al. (2010) identified another limiting factor potentially affected by forestry practice: low mortality.

Deciphering the factors that determine adaptation in the real forest, from the genes to the traits and from the traits to the performance, is complex. Each environment cannot be reduced to only one parameter, e.g. altitude combines temperature, soil, rainfall, biotic factors etc. Similarly, each performance, e.g. survival in stress conditions, can be achieved by different combinations of functional trait values. Finally, each value of a functional trait can be obtained by different combinations of gene alleles and interactions. As a consequence, one can hardly attribute a fixed intrinsic adaptive value to each physiological trait or to each gene allele. This complexity is also a chance for adaptation because it provides flexibility and there are multiple biological pathways to reach an ecological solution.

Forest management can enhance forest adaptation to climate change in three ways. Firstly, a full-control strategy consists in replacing the local population by a presumably better fit population. This is achieved through plantation of socalled forest reproductive material, which either comes from a breeding program or from a selected seed stand. This strategy allows for drastic stepwise evolutions, but it requires minimizing uncertainties about the ecological integration of the alien resource in the new site under future climates. Secondly, a driving strategy consists in guiding, i.e. supporting and accelerating, natural evolutionary processes using the local genetic resource, ecologically integrated within its current environment. This is achieved through natural regeneration. This strategy only produces progressive changes, limited by the evolutionary potential of the local resource, but it is flexible and relaxes the ecological uncertainty related to introduction of alien material. Thirdly, a combined strategy would follow the driving strategy after enrichment of the local resource with a certain amount of alien material in order to increase the evolutionary potential and to accelerate evolution 
while limiting the ecological uncertainty due to introduction. Since the first approach has already been treated elsewhere and deserves a complete treatment, e.g. see St Clair and Howe (2007) for a concrete experience in Pseudotsuga menziesii, we focus here on the second and third strategies. Three main questions emerge in this context: (1) How fast can tree populations respond to changes? (2) Will the populations keep their capacity to adapt to both continuous and unpredictable changes? (3) How can forestry practice affect, positively or negatively, the properties of adaptation and adaptability through time? Due to the complexity of evolutionary mechanisms interacting with highly diverse local conditions and climate change scenarios, the first two questions can only receive case-specific answers. Here, we call evolutionoriented forestry a particular form of adaptive forestry that integrates the enhancement of evolutionary processes among its possible objectives, and we propose a process-based approach to investigate the impact of silviculture on the evolution and evolvability of tree populations facing climate change.

In a first part, we describe the basic evolutionary mechanisms using a limited number of parameters in order to define a simple analytical grid. We show how these few parameters can help understand complex situations. The analytical grid also provides a mechanistic interpretation of the evolutionary constraints mentioned above. Secondly, we use this analytical grid to evaluate the potential effects of current forestry practice and to suggest other silvicultural options that could preserve as much as possible the objectives of forestry while driving the tree populations into faster evolutionary changes. Finally, we review the possible genetic tools available for monitoring adaptive changes and evolutionary processes and conclude with future perspectives for experimental management and research.

\section{The basic mechanisms driving genetic changes as an analytical grid}

Genetic diversity is continuously changing: Each sexual reproduction event generates new and unique genotypic combinations, some of which are then eliminated by selection and random processes. The strength of selection and genetic drift can be efficiently approached with a limited number of parameters. A wide range of evolutionary scenarios can be obtained when considering the interactions between selection, genetic drift, gene flow and plasticity. Due to the short term considered here, we neglect the effect of mutation.

\subsection{Single and multitrait response to selection}

Selection is the elimination of the less fit, due to low reproduction or mortality. A selection pressure on one trait can change the mean of the population (directional selection), or its variance (stabilizing or disruptive selection), or both. Although it does not integrate all the biological processes that effectively operate, the model of quantitative genetics (Falconer 1960), which assumes that a large number of genes interact with the environment to determine the phenotypic variation of each trait, has long proven a remarkable predictive value throughout all the practical achievements in plant and animal breeding programmes since mid-twentieth century. This model predicts the rate of change of trait mean per generation under direct directional selection as:

$$
\begin{aligned}
& R=i . h . \sigma_{A} \\
& \text { or, expressed in phenotypic standard deviation units, } \\
& \quad R^{\prime}=R / \sigma_{P}=i . h^{2}
\end{aligned}
$$

where

$i \quad$ Is the intensity of selection, i.e. mean differential between the adults that contribute and those that do not contribute to the next generation expressed in standard deviation units ( $i$ directly relates to the proportion of selected individuals)

$h$ Is the square root of the narrow sense heritability, which is the ratio between the additive genetic variance and the phenotypic variance $\left(h^{2}=\sigma_{A}^{2} / \sigma_{P}^{2}\right)$

$\sigma_{A}^{2} \quad$ Is the additive genetic variance

$\sigma_{P}^{2} \quad$ Is the phenotypic variance

Natural selection does not operate directly on the traits but on the global fitness of the individuals. Therefore, the response of each trait to natural selection is a type of indirect selection, and the previous equation is slightly modified as: $R=\beta . \sigma_{A}^{2}$ where $\beta$ is the partial regression coefficient of the fitness on the trait, or selection gradient. This formulation extends to the multitrait case where the response on each trait integrates its correlations with other selected traits (Lande and Arnold 1983). Finally, selection is summarized with only four basic parameters: $\sigma_{P}^{2}, \sigma_{A}^{2}, i$ (direct selection) or $\beta$ (natural selection).

Based on a review of empirical studies in all kinds of organisms, Gingerich (2009) found relatively high rates of evolution $\left(R^{\prime}\right)$ in the magnitude of 0.1 to 0.3 phenotypic standard deviation per generation, similar for longterm evolution and micro-evolution. Figure 1 shows the expected rate of change of a single trait under direct selection with different values of heritability and selection intensity. As explained in the next section, forest management can modify $i$ and, therefore, proportionally change $R^{\prime}$. 
Fig. 1 Expected rate of change per generation $\left(R^{\prime}\right)$ for a single selected trait under direct selection, expressed in phenotypic standard deviation units, for different values of heritability $\left(h^{2}\right)$ and different selection intensities $(i)$. Assuming a Gaussian distribution of the trait, elimination of 25,50 or $75 \%$ of the population corresponds to values of $i=0.42,0.80$ or 1.27 , respectively. The range of empirical values of $R^{\prime}$ found in the literature by Gingerich (2009) lies between the dotted lines

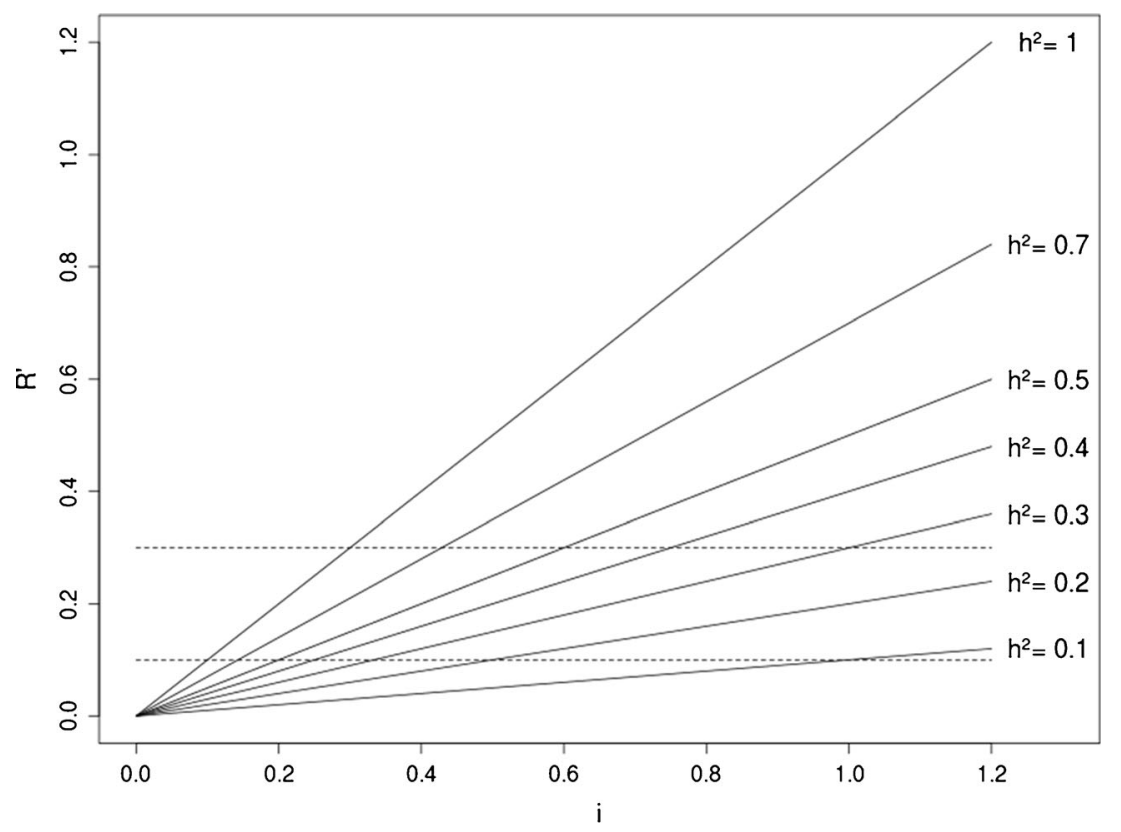

A trait will respond to selection if three conditions are simultaneously met (Endler 1986): (1) there is phenotypic variation within the population, (2) this variation is heritable and (3) this variation is correlated with the variation of fitness. Each term in the equation above is not fixed, but it varies depending both on the environment (Charmantier and Garant 2005) and the genetic background of the population (Carter et al. 2005). Natural selection in trees is a complex process because the selection pressure varies between years and it can drastically change between life stages both in direction (e.g. shift in selective forces between a dense seedling patch under the canopy and the adult stage) and in intensity (e.g. mortality rate is much higher at juvenile stage while selection on reproductive success only occurs at adult stage). Thanks to this variability of the parameters, the response to selection does not systematically correlates with a total exhaustion of the genetic variation within populations: The partitioning of the genetic variance of adaptive traits into between- and within-population components ( $Q_{\text {st }}$ approach) has revealed that a large part of the genetic variance of functional traits is maintained within population (Alberto et al. 2013, for a review), and an absence of within population genetic variance for a quantitative trait has exceptionally been reported in trees (SáenzRomero et al. 2006). Interestingly, the genetic architecture of a trait, i.e. the system of genes involved in the variation of the trait and their interactions with other traits, simultaneously determines long-term persistence of evolvability by a capacity to release cryptic variation in a new environmental or genetic context (Le Rouzic et al. 2007) as well as a potential limit to selection in case of detrimental genetic correlations (Walsh and Blows 2009). Functional constraints, resulting in environmental correlations between traits, can also limit the response to selection. Not included into this predictive model, epigenetic effects, i.e. environmentally determined heritable modification of gene expression, can also contribute to adaptation to sudden changes (Bossdorf et al. 2008; Skrøppa et al. 2010).

\subsection{Random changes due to genetic drift and mating system}

Genetic drift accounts for the reduction of genetic diversity that occurs in small populations, in absence of selection, mutation or migration, due to the variation of allele frequencies after random sampling from one generation to the next. Furthermore, small populations are prone to increased inbreeding due to the higher probability of mating between relatives. Inbreeding has a twofold effect: It reduces fitness whenever inbreeding depression is present, and it retains non-random association of gene alleles (linkage disequilibrium) at higher rate which represents a reduction in the diversity of genotypic combinations. Non-random mating system can also affect inbreeding: The mating system varies among individuals and populations, including selfing rate (most of tree species are not dioecious) and diversity of pollen donors, depending on the relative fecundity and spatial distribution of reproducing trees.

Under the assumptions of Wright-Fisher's model population (Wright 1931), the reduction of gene diversity and the increase of inbreeding are driven by one single parameter, population size. Using this model as a reference, the effective population size $\left(N_{\mathrm{e}}\right)$ of a real population of size $N$ that has a per-generation rate of reduction of gene diversity $\left(\Delta H_{\mathrm{e}}\right)$ or increase of inbreeding $(\Delta F)$ is such that: $\Delta H_{\mathrm{e}}=-1 / 2 N_{\mathrm{e}}$ or $\Delta F=1 / 2 N_{\mathrm{e}}$. It can be shown that, in the absence of dominance, $N_{\mathrm{e}}$ also measures the per-generation rate of reduction of 
additive variance: $\Delta \sigma_{A}^{2}=-1 / 2 N_{e} . N_{\mathrm{e}}$ is defined on the rate of change of gene diversity or inbreeding, not on the actual population size $N . N_{\mathrm{e}}$ is most often not directly estimable in natural populations (unless longitudinal estimates of gene diversity, $H_{\mathrm{e}}$ or $\sigma_{A}^{2}$, or inbreeding, $F$ ), but its changes can be predicted and decreasing $N_{\mathrm{e}}$ means intensifying the intensity of genetic drift. When the actual population only departs from the theoretical model by relaxing the assumption of Poissonian distribution of reproductive success, it can be shown that: $N_{\mathrm{e}}=(4 N-2) /(V+2)$ where $V$ is the actual variance in reproductive success, i.e. $N_{\mathrm{e}}$ decreases substantially in proportion to this variance.

Tree populations are generally assumed to have large effective population size (Petit and Hampe 2006), in part because they are outcrossing and disperse their genes over long distances in particular through pollen (Ashley 2010); thus, they should not be too much affected by genetic drift. In their review, Schoen and Brown (1991) found $N_{\mathrm{e}}$ estimates for tree species in the range of other outbreeding plants: mean values around 3,000 for Pseudotsuga menziesii and >8,000 for Pinus sylvestris and Picea abies, with high variations among populations within each species. However, locally, seed and pollen contributions to reproduction are highly uneven among individuals (Burczyk et al. 2002; Krouchi et al. 2004; Oddou-Muratorio et al. 2005), and the great majority of the pollen disperses only in the close neighbourhood, which can greatly reduce the effective population size. In their review, Smouse and Sork (2004) found that the effective pollen pool size $N_{\text {ep }}$, defined as the inverse of the probability that a female draws two offsprings from the same father, ranges from 2 to 200 in tree populations. $N_{\text {ep }}$ can be very small in some populations: Fragmented populations of wind pollinated species of Quercus humboldtii (Fernandez-M and Sork 2005) and Quercus alba (Smouse et al. 2001) exhibit estimates of $N_{\text {ep }}$ around 6 and 8, respectively. By contrast, in continuous forest populations, several examples estimate high values of $N_{\mathrm{ep}}$ : Robledo-Arnuncio et al. (2004) estimated a $N_{\mathrm{ep}}>70$ in a Spanish population of Pinus sylvestris. Fragmented populations, isolated populations and populations at low density have a higher risk of extinction due to the erosion of diversity by genetic drift (Goodell et al. 1997; Hardy et al. 2004; Robledo-Arnuncio et al. 2004; Aguilar et al. 2008).

\subsection{Interactions between selection, drift, gene flow} and phenotypic plasticity

A well-known interaction between drift and selection is the vortex of extinction (Gilpin and Soule 1986): when there is a genetic load in the population, a rapid decrease in population size leads to increased genetic drift and increased inbreeding, resulting in reduced mean fitness that further reduces population size, which over time will result in extinction in a geometric decline. However, there is no experimental evidence to our knowledge that this kind of extinction vortex ever occurred in trees. Alternatively, resistant genotypes that emerge in the population increase their contribution to the next generation and can restore population growth if not eliminated at random, a process known as evolutionary rescue (Gomulkiewicz and Holt 1995). Whether populations can be rescued depends on population size, genetic diversity and the degree of maladaptation to the new environment.

In the case when the environment changes both in space and time, gene flow can bring into the population pre-adapted genes (Pease et al. 1989; review by Kremer et al. 2012). Kuparinen et al. (2010) showed that pollen and seed dispersal at longer distance speed up the adaptation process. In tree populations, it is expected that pollen-mediated rather than seed mediated gene flow will contribute to this processes, with average pollination distances commonly being hundreds of meters (Ashley 2010), and maximum distance of $100 \mathrm{~km}$ measured in Pinus sylvestris airborne transported pollen (Robledo-Arnuncio 2011). In this species, along a latitudinal gradient, Nilsson (1995) showed that long-distance pollen migration brings into the population new phenotypes with a phenology specific of other locations. Local individuals with extreme phenotypic values, in particular for flowering phenology, are keen to catch more long-distance pollen grains because they are better synchronized with source population of interest and also because they are less saturated by local pollen.

Abundant theoretical literature exists on the role of phenotypic plasticity in evolution; recent reviews of predictions on the interaction between selection and plasticity in the context of climate change can be found in Chevin et al. $(2010,2012)$, the second review also provides key references of empirical studies of plasticity in trees. Maladaptive plasticity is obviously detrimental to adaptation. When adaptive plasticity is not genetically variable, it is expected to slow down the genetic response to directional selection in each generation but also to allow the phenotypes to track the environmental change more closely. The sustainability of this process of adaptation depends on the fitness cost of plasticity. When adaptive plasticity varies genetically, i.e. there is $G \times E$ interaction and plasticity can evolve, the amount of genetic variance of the plastic trait depends on the environment: If the new environment increases the genetic variance, then plasticity tends to accelerate the genetic response to selection and plasticity is itself selected for (Lande 2009). Considering a steep spatial environmental gradient, where gene flow interacts with selection and plasticity, the evolution of plasticity is expected to allow the population to explore a larger range, and marginal habitats are expected to show higher plasticity (Chevin and Lande 2011). A further degree of complexity arises when considering the interplay between abiotic environment, biotic interactions and evolutionary processes (Box 1). 


\section{Potential effects of forestry practice on the rate of evolution of trees}

3.1 A global framework to assess the evolutionary impact of silviculture

Considering the evolutionary impact of silviculture is thus an additional requisite to adaptive forestry. While facing climate change and uncertain future, forestry practice should simultaneously accelerate genetic adaptation by helping tree populations to track the known environmental changes and preserve the genetic diversity as a reservoir of future options to respond to the next unknown changes. This is a classical challenge in breeding programs: obtaining a rapid genetic gain while keeping the potential for long-term response to selection. Breeders solve this problem by combining selection and recombination. Genetic adaptation occurs if better performing genotypes emerge during reproduction and if the best performing genotypes spread in the population before extinction. Therefore, we can assign three objectives to evolutionoriented forestry practice: (1) increase the chance of emergence of 'innovative' genetic combinations, (2) facilitate the spread of the best adapted genotypes and (3) preserve genetic diversity for long-term response to selection. Acting simultaneously on the demography and the environmental conditions, silviculture has an impact on the parameters of selection and genetic drift. Due to the multiplicity and complexity of the processes involved and to the huge diversity of biological and environmental features among forests, it is more reliable to predict the effects of silviculture on the parameters of evolution rather than on the final state of the genetic diversity. Thus, silviculture should aim to limit the intensity of genetic drift, increase the diversity of mating pairs, avoid counter-selection and maintain selection pressure in the right direction, reduce inbreeding etc. Here, we briefly consider the evolutionary benefits, or risks, associated to current or future forestry practice. A more quantitative prediction of their balanced effects could rely on simulation studies using process-based models that explicitly integrate demographic, genetic and biophysical processes and allow to simulate interventions (Kramer et al. 2008).

\subsection{Foreseen evolutionary impact of common forestry practice}

A general consequence of silviculture on the drivers of evolution is the change of environmental conditions: competition and, possibly, other biotic or abiotic environmental factors. As mentioned above, the environmental conditions determines not only the phenotypic variance $\left(\sigma_{P}^{2}\right)$ of the traits but also the genetic variance $\left(\sigma_{A}^{2}\right)$, in case of $\mathrm{G} \times \mathrm{E}$ interactions, and the selection gradient that relates trait value to fitness $(\beta)$ (Fig. 2). Furthermore, increased canopy closure also affects pollen dispersal and mating system parameters: selfing rate $(s)$, effective pollen pool size $\left(N_{\mathrm{ep}}\right)$ and variance of reproductive success $(V)$ (García et al. 2005; Milleron et al. 2012).

Beyond these general effects, thinning, whether systematic or selective, will affect the spatial clustering of genetically related reproducing trees and their allocation to reproduction and, therefore, the mating system (Fig. 2). By removing neighbouring-related individuals, thinning may reduce spatial genetic structure and, consequently, inbreeding in the regeneration (Dounavi et al. 2002). Sagnard et al. (2011) showed that, when the density of seed trees is low $\left(<16\right.$ treesha $\left.^{-1}\right)$, a clustered distribution of seed trees will produce less spatial genetic structure in the seedlings than a random or dispersed distribution. Robledo-Arnuncio et al. (2004), in Pinus sylvestris, and Restoux et al. (2008), in Abies alba, found at seed stage that low densities of reproductive trees simultaneously increase the probability of selfing (from $<5$ to $>20 \%$ ) and the diversity of the outcrossing pollen $\left(N_{\mathrm{ep}}\right)$, which can be mechanistically explained by a higher rate of long distance pollen pollination (Klein et al. 2006). Therefore, lower seed trees density can result in higher genetic diversity at seedling stage, whenever pollen is not limiting and purge of inbreeding occurs early, but it can be a risk when pollen is limiting, which must be considered in the context of climate change.

When the local population size is limited, a genetic drift effect may result from the reduction of the number of reproducing trees, leading to a loss of rare alleles (among which currently deleterious genes). Such effect was observed in old-growth forests of Pinus strobus comparing pre- and post-harvest stands $(>100$ and $<30$ trees, respectively) (Buchert et al. 1997; Rajora et al. 2000), as well as in Picea rubens old growth forests (Mosseler et al. 2003). Konnert and Hussendörfer (2001) compared 16 even-aged and nine uneven-aged management systems in $A$. alba, several forests for each group and also the two management systems within the same forest: They found a slightly higher number of rare alleles but smaller number of different gametic combinations in the uneven-aged forests. However, there are too few studies of this type to draw general conclusions on an eventual intrinsic difference between these two management systems regarding their effects on the genetic diversity. The drift effect is not a priori limited to the managed population but it may also affect secondary tree species as observed for Abies amabilis, Tsuga heterophylla, Thuya plicata and Pinus monticola in Pseudotsuga menziesii forests by El-Kassaby and Benowicz (2000).

In naturally regenerated stands, reproductive trees usually result from successive selective thinnings for their phenotypic value such as stem vigour, health consideration, lack of defects like thick branches or forked or twisted trunk, as 


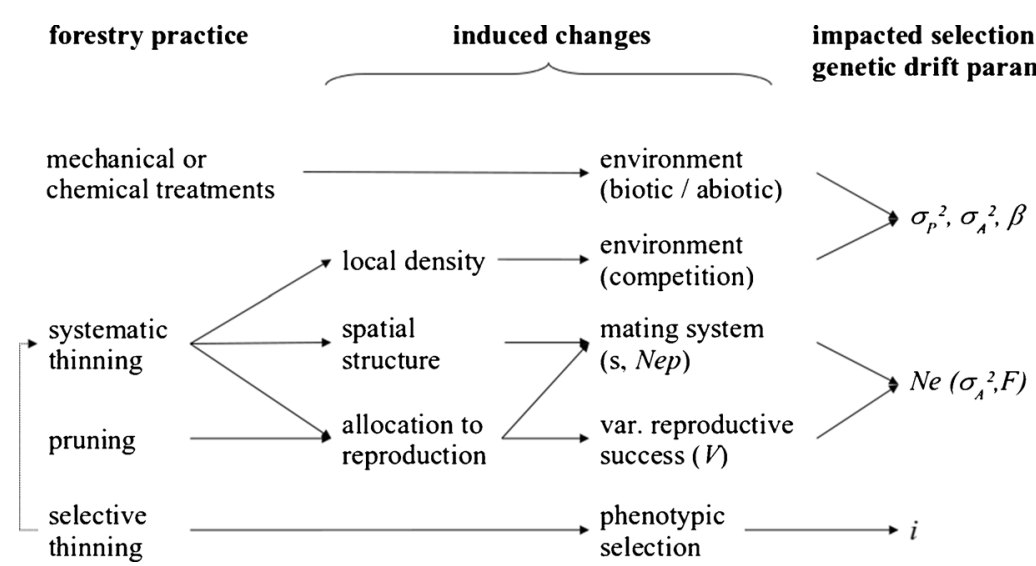

Fig. 2 Expected effects of forestry practice on evolutionary processes: schematic pathway from the forestry management in natural regeneration systems to the selection and genetic drift parameters. See text for explanation of the paths ( $\sigma_{P}^{2}$ phenotypic variance, $\sigma_{A}^{2}$ additive genetic variance, $\beta$ selection gradient for natural selection, $i$ selection intensity for direct selection, $s$ selfing rate, $N_{e p}$ effective pollen pool size, $V$ variance of reproductive success, $N_{e}$ effective population size, $F$ inbreeding) well as for their spatial distribution in order to reduce competition. In Fagus sylvatica, selective thinning favouring the most vigorous trees was found to increase the heterozygosity by 4 to $9 \%$ (Lauber et al. 1997; Dounavi et al. 2002), even when selection occurs at a very early stage (Thiebaut et al. 1992). However, this effect was not detected in other studies on A. alba (Hussendörfer and Konnert 2000) or Pinus contorta (McDonald et al. 2001). We must remind here that an increase in heterozygosity during maturation of forest stands is frequently observed and that natural selection of seedlings can start at a very early stage in overstocked young regeneration (Pichot et al. 2006). Selective thinning favouring the best growing trees may act as selection for competing ability: Assuming a Gaussian distribution of tree height, the elimination of the $25 \%$ (resp. $50 \%$ ) smallest individuals represents a selection intensity $i=0.42$ (resp. 0.80) on this trait. Selective thinning may also integrate a direct selection on other traits chosen by the forester (Fig. 2). We need to understand more clearly which functional traits are indirectly selected for and how these traits relate to future fitness in the context of changing climate. One main question that still needs to be addressed is how far silviculture will intensify selection for juvenile vigour and, if this is the case, how far juvenile vigour is genetically positively or negatively correlated with drought resistance.

The intensity of genetic drift, through the variance in reproductive success, and the mating system not only depends on the number and spatial distribution of reproductive trees but also on their allocation to reproduction. As indicated in Fig. 2, this allocation is influenced by local stand density as well as other practices like pruning (Ayari et al. 2012). Thinning and pruning also affect the plasticity, which will interact with selection processes as previously mentioned: The question here is whether the plastic response induced by the silviculture is adaptive or maladaptive regarding future climate change.

Multiple forestry practices may also be combined and interact to modify the microenvironmental conditions of development, generally as to reduce stress and competition in order to favour growth (Forrester et al. 2012). Thus, after an extreme drought event in 1976, stand decline was reduced in Picea abies stands that had previously been thinned in 1971 (Misson et al. 2003): Compared to the control plot, heavy thinning had a more beneficial impact than moderate thinning (thinning from 36 to 14 or to $20 \mathrm{~m}^{2}$ $\mathrm{ha}^{-1}$ basal area, respectively). We are not aware of any study of the effects this could have on plasticity (e.g. reduced acclimation to future stress) and selection. As a case study, we present the analysis of evolution and potential effects of silviculture in the situation of highly heterogeneous environment within the forest (Box 2).

\subsection{Evolutionary benefits and risks expected from some silvicultural recommendations related to climate change}

New forestry practice is progressively implemented to reduce ecological and economic risks related to climate change (Legay and Mortier 2005; Yousefpour et al. 2012). From an evolutionary point of view, reducing environmental stress has a twofold effect. On the one hand, it reduces the damages and therefore contributes to increase the effective population size $\left(N_{\mathrm{e}}\right)$, which is a crucial issue when population size is already small or is expected to decrease drastically due to severe damages. But, on the other hand, it also slows down the genetic improvement in the next generation by reducing selection intensity $(i)$, and it does not exploit potential adaptive plasticity (no acclimation to future stress), which is an important issue to consider in large populations. 
We briefly consider here some of these practices, or changes in practices, from the evolutionary point of view and illustrate their possible balanced effects. In all cases, whenever applying new practice, it is crucial to keep precise records of what is done, how and when, in order to facilitate future evaluation ex post, in particular after marked climatic events.

Shortening rotation reduces the probability of the risk, e.g. to extreme climatic events, but it can also increase the vulnerability to the risk if shorter rotations select for higher juvenile vigour and if juvenile vigour is genetically negatively correlated with stress resistance. Both of these conditions still have to be investigated. The answer will probably depend on the species, on the environment and on the management system considered.

Reducing the density of stands is envisaged to reduce the effective drought stress supported by the trees. However, this immediate positive effect may be partly balanced by a long-term detrimental effect on selection by inducing a maladaptive phenotypic response and by reducing selective mortality (see first section). This risk is reduced if time is left for sufficient natural selection to proceed before thinning. More generally, from the evolutionary point of view, interventions occurring at juvenile stage raise the question of age-age correlations. Apart from the temporal changes in environmental conditions, life stages differ in their physiology and development. During the complex and temporally changing selection process in trees, juvenile-adult genetic correlations contribute to determine how far a selection pressure (or release of selection) during the juvenile stage will genetically affect the adult population. This issue can hardly be addressed in situ. Partial answer, here again, comes from the breeding experience and early selection schemes. Studies on growth and wood density in different Pinus species revealed that genetic age-age correlation $>0.8$ is generally achieved from the age of 10-12 years (Hannrup and Ekberg 1998; Gwaze et al. 2000; Wu et al. 2007; Bouffier et al. 2008). It varies greatly with environmental conditions, and in Pinus radiata, this level of correlation can be reached as soon as $2-5$ years in certain sites (Gwaze et al. 2000; Wu et al. 2007). Matheson et al. (2002) showed that genetic age-age correlations in Pinus radiata also vary with the genetic background with higher correlations in presence of inbreeding. Thus, silviculture may have an effect on age-age correlations through its effects on the environmental conditions and on the genetic background. Further investigations on age-age correlations of functional traits are deeply needed.

In the case of massive dieback, sanitary logging is necessary to reduce the spread of primary or secondary parasites, and it can also be necessary for fire prevention or for the protection of forest users. However, excessive elimination of surviving trees could result in the elimination of resistance to the pathogen (Burke 2011).

\subsection{Evolution-oriented forestry, why not?}

We imagined some specifically evolution-oriented forestry practices in the case of natural regeneration management system (Table 1). These interventions should not be directly considered as recommendations or guidelines as such; we rather propose them as case studies to illustrate innovative adaptive forestry that would take into account short- and long-term evolutionary potential, still to be associated with other clues. This is not an exhaustive list, and any combination of the proposed interventions can be envisaged.

In order to reduce the intensity of genetic drift (increase $N_{\mathrm{e}}$ ) in small populations, silviculture may be oriented towards reduced variance of fecundity $(V)$ between trees: Reducing $V$ will not only increase $N_{\mathrm{e}}$ within each annual seed production, as mentioned above, but it will also reduce the fluctuation of effective contributions across years and thus increase pluri-annual $N_{\mathrm{e}}$ estimates (Krouchi et al. 2004) . This would be another objective assigned to thinning and pruning. It requires a balance between keeping sufficient number of seedling trees and sufficient spacing between them (optimisation should be made on a case-by-case basis, depending on dispersal capacities). Due to the tree $\times$ year interaction effect on the variation in fecundity generally observed in trees, a general recommendation would be to cumulate reproduction during several years. Actually, current practice may already be optimal for this purpose. A negative side effect is to slow down the elimination of detrimental alleles (Couvet and Ronfort 1994) and reduce the response to selection. A compromise between preserving the genetic diversity for the future (reduce genetic drift) and accelerating the immediate response to selection could be to equalize the mating success per patch, in particular when the environment is spatially heterogenous (Box 2).

In order to reshuffle the local genetic diversity and increase genetic recombination, silviculture could enhance local gene flow, either through artificial dispersal of local seeds or by assisting pollen dispersal. With the same objective, isolated seed trees should be considered with care: From one side, they may have a higher selfing rate but, on the other side, they can capture long distance pollen flow. If selfed seeds are eliminated at an early stage of development (e.g. empty seeds in some conifer species), the fertile seeds hamper a large genetic diversity. In the case of heterogeneous environment within the forest, areas for wood production and areas for evolution could be spatially dissociated while maintaining gene flow between these entities (Box 2).

In an environmental cline, typically an altitudinal cline, a strategy might be to accelerate the migration of the population towards more favourable areas. The velocity of migration depends on the effective dispersal, and effective dispersal is highly dependent on the local conditions for 
Table 1 Some examples of evolution-oriented forestry practice, including re-orientation of usual interventions (no supplementary cost) and additional interventions

\begin{tabular}{|c|c|c|}
\hline Forestry practice & Expected benefits & Associated costs and risks \\
\hline $\begin{array}{l}N_{\mathrm{e}} \text {-oriented regulation of the density and spatial } \\
\text { distribution to equalize reproductive success } \\
\text { between trees in small populations }\end{array}$ & $\begin{array}{l}\text { Reduce the variance in reproductive } \\
\text { success to reduce genetic drift } \\
\text { Reduce spatial genetic structure in the } \\
\text { seedlings and inbreeding in next } \\
\text { generation }\end{array}$ & $\begin{array}{l}\text { No supplementary cost } \\
\text { Risk to slow down the elimination of detrimental } \\
\text { genes, prefer equalization of mating success per } \\
\text { patch (compatible with the next line) }\end{array}$ \\
\hline $\begin{array}{l}\text { In heterogeneous environment, dissociate areas of } \\
\text { production and areas of evolution (selection } \\
\text { patches in harsh areas) and allow gene flow } \\
\text { between these entities }\end{array}$ & $\begin{array}{l}\text { Increase the reproductive contribution } \\
\text { of the trees that have survived to } \\
\text { drastic selection pressure }\end{array}$ & $\begin{array}{l}\text { Limited supplementary cost } \\
\text { Requires preliminary simulation studies to } \\
\text { estimate benefits in various contexts (strength } \\
\text { and spatial structure of the environmental } \\
\text { heterogeneity) }\end{array}$ \\
\hline $\begin{array}{l}\text { Save the lone tree, which cumulates long distance } \\
\text { dispersal (in allo-pollinated seeds) and can be } \\
\text { adapted to marginal conditions; collect seeds for } \\
\text { local assisted regeneration }\end{array}$ & $\begin{array}{l}\text { Diversify the mating pairs to favour the } \\
\text { emergence of new genotypic } \\
\text { combinations } \\
\text { Promote adaptation to marginal } \\
\text { conditions }\end{array}$ & $\begin{array}{l}\text { Limited supplementary cost } \\
\text { Requires a protocol for assisted regeneration } \\
\text { Risk of inbreeding if self-pollinated seeds are not } \\
\text { purged at a very early stage (e.g. seed abortion) }\end{array}$ \\
\hline $\begin{array}{l}\text { Assisted local seed dispersal (e.g. collecting, } \\
\text { possibly over several years, mixing and } \\
\text { replanting seeds within the stand) or pollen } \\
\text { dispersal (e.g. air flow used in seed orchards) }\end{array}$ & $\begin{array}{l}\text { Enhance local gene flow to diversify } \\
\text { the mating pairs and favour the } \\
\text { emergence of new genotypic } \\
\text { combinations }\end{array}$ & $\begin{array}{l}\text { Potentially significant supplementary cost } \\
\text { Requires preliminary studies to estimate benefits } \\
\text { in various contexts (genetic diversity and spatial } \\
\text { structure) }\end{array}$ \\
\hline & Reduce inbreeding & Requires a protocol for assisted regeneration \\
\hline $\begin{array}{l}\text { Enhance local migration capacity by favouring } \\
\text { seed dispersal and germination at distance from } \\
\text { the main stand }\end{array}$ & $\begin{array}{l}\text { Speed-up colonisation of locally } \\
\text { favourable habitats in an } \\
\text { environmental gradient }\end{array}$ & Potentially significant supplementary cost \\
\hline $\begin{array}{l}\text { Genetic enrichment by introduction of a limited } \\
\text { amount of seeds or pollen from presumably pre- } \\
\text { adapted allochthonous origins }\end{array}$ & $\begin{array}{l}\text { Introduce pre-adapted genotypes } \\
\text { Increase local genetic diversity }\end{array}$ & $\begin{array}{l}\text { Potentially significant supplementary cost } \\
\text { Risk of gene swamping and reduction of effective } \\
\text { population size }\left(N_{\mathrm{e}}\right) \text { if local population is small } \\
\text { and if introduced material has low genetic } \\
\text { diversity } \\
\text { Risk of unforeseen local maladaptation }\end{array}$ \\
\hline Marker-assisted selective thinning (futurist) & $\begin{array}{l}\text { Increase selection intensity on target } \\
\text { major genes while retaining genetic } \\
\text { diversity in the rest of the genome }\end{array}$ & $\begin{array}{l}\text { High supplementary cost } \\
\text { Requires accurate genetic knowledge and high- } \\
\text { throughput genotyping capacities }\end{array}$ \\
\hline
\end{tabular}

See text and Box 2 for further explanation

seedling establishment conditions (Amm et al. 2012). We can imagine to enhance seed germination and seedling growth by preparing the soil or controlling competition and predation at distance from the core of the population, in the direction wanted for migration. For zoochorous species, we can also imagine to attract seed dispersers along the wanted migration route (Oddou-Muratorio et al. 2004; García et al. 2009; Schleuning et al. 2011).

Genetic enrichment of the local genetic resource by the introduction of a limited amount of allochthonous material from a putatively pre-adapted origin, through seed or pollen introduction, could present a twofold benefit of introducing gene alleles of interest and increasing the global genetic diversity. To avoid gene swamping effect and reduction of the effective population size, it is essential to use a large genetic base of the introduced material (Lefèvre 2004). For long-lived organisms, it is also important to anticipate a possible trade-off between adaptation to long-term climatic trend and adaptation to current conditions and/or to annual fluctuations, such as vulnerability to late frost of early flushing genotypes.

As a complete utopy, we can imagine future access to intensive genotypic data on each adult tree. Inspired from the marker-assisted selection strategies used in plant and animal breeding, marker-assisted selective thinning could combine the objectives of increasing the adaptive change for the target traits that are unambiguously identified while preserving the maximum diversity in the rest of the genome.

\section{Genetic monitoring and study tools}

In a recent publication, Hansen et al. (2012) reviewed the different tests and approaches for genetic monitoring of adaptive changes using phenotypic or molecular tools. Their focus was on the capacity to demonstrate the adaptive 
response and rule out alternative hypotheses that might explain the genetic change. In this section, we investigate how far recent genetic monitoring methods and tools can help to rationalize evolution-oriented forestry.

\subsection{What is new in molecular and phenotypic tools?}

A comprehensive review of the genetic markers and their use in trees was published by Prat et al. (2006). Almost all kinds of markers have been developed on one or several tree species, and they were mainly used to infer on the neutral genetic diversity and neutral processes (drift, mating system, dispersal). With the classical genome sequencing projects, which started in the 1990s for trees, a gap in terms of available tools had progressively appeared between a very limited number of model tree species and the other species. In the last 3 years, recent advances in DNA sequencing have revolutionized the field of genomics making it possible to generate a large amount of sequences and markers in timeand cost-effective way. Nowadays, thanks to the emergence and evolution of the so-called next generation sequencing techniques and related bioinformatics (Metzker 2009; Kircher and Kelso 2010), full-genome sequencing, reduced-representation sequencing and targeted sequencing are in progress not only for model species but also for nonmodel species where molecular monitoring is becoming worth considering from scratch. Evidence of genetic changes at molecular level in trees has recently emerged from the direct study of genome wide DNA polymorphisms: evidence of the correlations between genotype frequencies and environmental gradients (Eckert et al. 2010) or climaterelated traits (Grivet et al. 2011), sometimes completed with functional information on the detected genes (Holliday et al. 2010). See also Alberto et al. (2013) for a recent review of single nucleotide polymorphisms associated to climate related traits in trees. However, as Rockman (2012) very wisely stated, the extraordinary potential of these approaches should not be misleading: Due to the genetic and environmental sensitivity of the response to selection as previously discussed, we should not expect to find many single gene alleles having large, constant and uniform effect in all populations. If such nucleotides are detected, we should not reduce the genetic variation to them because most of the genetic diversity of interest for adaptation to climate change will remain cryptic. These approaches will nevertheless be very useful in providing genetic indicators of the selection pressure.

The phenotypic approach of adaptation has also evolved in two directions. Firstly, the physiologists have produced proxies of physiological functions that can be measured in large sample size (hundreds of individuals). The relation between the measured trait and the actual function is generally indirect and requires careful interpretation, e.g. carbon isotope discrimination or ring density used as proxies of the response to drought (Osório and Pereira 1994; Tene et al. 2011). It is probably worth reminding that splitting an integrated phenotypic trait into simpler functional components does not resolve the complexity, e.g. functional components do not necessarily have higher heritability or simpler genetic determinism than the integrated trait, because new interactions and regulations appear at finer scale. Secondly, methodologies combining phenotypic and genotypic information have been developed to estimate genetic parameters (variances and correlations) in situ, i.e. in the natural environment, at any life stage and without requiring controlled pedigrees (Ritland 1996). To estimate selection gradients $(\beta)$ in trees, a common approach is to use performance traits like survival, growth or reproductive traits as proxies of fitness and study the impact of functional traits on these performance traits in controlled ex situ progeny tests. Using this approach in Quercus suber, Ramirez-Valiente et al. (2011) detected significant heritability but nonsignificant selection gradient for carbon isotope discrimination, contrasting with very low heritability and significant selection gradient for specific leaf area. An alternative approach of selection gradients through the assessment of actual reproductive success in situ was recently developed (Oddou-Muratorio et al. 2005; Burczyk et al. 2006; Klein et al. 2011). This method, based on the mixed-mating neighbourhood model, consists in estimating the reproductive success of individual adult trees using spatial genetic data of seedlings and their potential parents and then in relating this reproductive success to phenotypic traits. Bontemps (2012) used this method in a marginal population of $F$. sylvatica: In this case, the author found significant heritability and significant selection gradient for carbon isotope discrimination, contrasting with non-significant heritability and non-significant selection gradient for specific leaf area.

\subsection{Possible monitoring}

Various sets of state and pressure indicators have been proposed for the monitoring of the genetic diversity in forest trees, based on direct genetic assessment or indirect observations through the demography and ecology of the populations (Namkoong et al. 1996; Brown et al. 1997; Koski et al. 1997; Lefèvre and Kajba 2001; Aravanopoulos 2011). Table 2 briefly reviews the possible uses of molecular and phenotypic tools, and the requirements of these uses, for genetic monitoring of adaptation. We distinguish two main objectives for genetic monitoring: (1) quantification and characterization of the genetic diversity and (2) monitoring of the drivers of genetic changes.

The genes controlling the variance of most adaptive traits (quantitative trait loci, QTL) are expected to be numerous 
Table 2 Objectives and requirements of genetic monitoring using molecular and phenotypic tools

\begin{tabular}{|c|c|c|c|}
\hline \multirow[t]{2}{*}{ Monitoring objectives } & \multicolumn{3}{|l|}{ Requirements } \\
\hline & Molecular tools only & Phenotypic tools only & Combined approach \\
\hline \multicolumn{4}{|l|}{$\begin{array}{l}\text { Quantification and characterization } \\
\text { of the genetic diversity }\end{array}$} \\
\hline $\begin{array}{l}\text { Quantify the global genetic diversity } \\
\text { and characterize its organisation }\end{array}$ & Neutral markers & - & - \\
\hline $\begin{array}{l}\text { Decipher the genetic architecture of } \\
\text { adaptive traits (QTLs, variances and } \\
\text { correlations) }\end{array}$ & $\begin{array}{l}\text { Known pedigrees, validated } \\
\text { candidate genes } \\
\text { polymorphisms }\end{array}$ & $\begin{array}{l}\text { Known pedigrees, common } \\
\text { garden experiments (ex situ) }\end{array}$ & $\begin{array}{l}\text { QTL mapping or QTL } \\
\text { association studies, ex situ } \\
\text { experiments } \\
\text { and in situ methods }\end{array}$ \\
\hline \multicolumn{4}{|l|}{ Monitoring the drivers of genetic changes } \\
\hline $\begin{array}{l}\text { Monitor recent changes in demography } \\
\text { and genetic drift intensity }\end{array}$ & $\begin{array}{l}\text { Neutral markers, multi- } \\
\text { generation sampling }\end{array}$ & - & - \\
\hline $\begin{array}{l}\text { Monitor the mating system and } \\
\text { hybridization }\end{array}$ & $\begin{array}{l}\text { Neutral markers, multi-cohort } \\
\text { sampling }\end{array}$ & - & - \\
\hline $\begin{array}{l}\text { Characterize pollen and seed dispersal } \\
\text { functions }\end{array}$ & $\begin{array}{l}\text { Neutral markers, seed or/and } \\
\text { seedling samples }\end{array}$ & Pollen and seed traps & Combined approach possible \\
\hline Detect signatures of past selection $(\beta)$ & $\begin{array}{l}\text { Genome wide markers and } \\
\text { candidate genes } \\
\text { polymorphisms }\end{array}$ & - & - \\
\hline Monitor current selection gradient $(i, \beta)$ & $\begin{array}{l}\text { Validated candidate genes } \\
\text { polymorphisms, multi- } \\
\text { generation sampling }\end{array}$ & $\begin{array}{l}\text { Known pedigrees, path analysis } \\
\text { traits to performance, ex situ } \\
\text { experiments }\end{array}$ & $\begin{array}{l}\text { Selection gradient studies, in } \\
\text { situ methods }\end{array}$ \\
\hline
\end{tabular}

See text for further explanation

QTL quantitative trait loci

with small individual effect. This is confirmed by empirical results, even though molecular tools only detect a small fraction of these QTLs. The QTLs and their genetic effects vary depending on the environment and the genetic background. Therefore, defining the adaptive genetic diversity as the whole set of QTLs potentially affecting fitness components, there is no strict frontier between neutral and adaptive genetic diversity: A gene polymorphism that is neutral in one context may become adaptive in another environmental or genetic context and vice versa. Thus, considering climate change and its uncertainties, quantification and characterization of both currently adaptive genetic diversity and currently neutral genetic diversity are needed. Classically, the overall genetic diversity is assessed with neutral markers (Buchert et al. 1997). Quantification and characterization of the current adaptive genetic diversity is assessed using phenotypic and molecular tools. Using only the phenotypic tools, the assessment of the genetic matrix of variances and covariances of adaptive traits requires known pedigrees and ex situ controlled experiments (preferable in trees for which deep pedigrees are not available in natural populations like in other organisms). Candidate gene polymorphisms, which include direct functional polymorphisms as well as linked markers, provide direct or indirect information on the diversity of target genes. When markers and phenotypic tools are combined, several approaches can be conducted: QTL mapping in known pedigrees and controlled conditions, QTL association to traits in controlled conditions and in situ studies of QTL association to the environment (Neale and Savolainen 2004).

All kinds of molecular tools of known heredity may provide information on the neutral drivers of genetic changes: genetic drift, mating system and dispersal. More interesting is to investigate the changes in these drivers, which generally requires transgenerational sampling. Genome-wide markers as well as candidate genes polymorphisms are now commonly used to detect signature of past selection events by testing a departure of the diversity pattern from the neutral expectation. Monitoring ongoing selection processes requires to relate directly the trait to the fitness or at least to a performance trait (selection gradient $\beta$ ). With phenotypic tools alone, trait to performance mapping can be assessed ex situ with known pedigrees. When molecular and phenotypic tools are combined, in situ selection gradient studies can be performed.

\section{Conclusion}

The adaptive capacity of tree populations is potentially huge, and silviculture can have a significant impact on the rate of phenotypic and genetic change per generation: The 
rate of change might probably be increased or reduced by a factor two depending on management interventions, which should not be neglected. The concept of evolution-oriented forestry that we introduced here does not pretend to allow for sufficient change in all cases. It should be considered as an option, with different associated benefits, risks and costs than those associated to the plantation strategy. Both strategies can also be combined. In any case, it is crucial to consider the potential evolutionary impact of silviculture when designing an adaptive forestry strategy. We proposed a simple framework to analyse and foresee the effects of forestry practice, and we identified a limited number of evolutionary processes and parameters that could be affected. Only few quantitative predictions can be made today, basically when evolutionary drivers are considered individually, and most expectations remain qualitative. Qualitative expectations can be used to draw research hypotheses. Quantitative predictions are needed to assess more precisely the cost effectiveness of forestry practice under various climate change scenarios. Quantitative comparison of evolution-oriented forestry with other baseline management options will require further process-based modelling and simulation studies for different forest types and species, different biotic and abiotic environments and different climate change scenarios. For a better understanding of the limits of the response to selection, we suggest to couple demogenetic models with biophysical models or host-parasite models.

One challenge for forestry decision-making under climate change is to reach a compromise between short-term and long-term objectives, e.g. speed-up the response to current selection pressure while preserving diversity and evolvability for uncertain future. A safe guideline is to favour natural selection for certainly adaptive traits, like drought resistance in the areas where more severe drought is expected, avoid random genetic erosion and increase genetic mixing. Over-selection for undue traits should also be avoided. As we have shown, each forestry practice has an effect on several evolutionary drivers (a geneticist would say pleiotropic effects) and interaction effects of different practices on a single evolutionary driver also exist (epistasis in genetic terms). To understand the global impact of forestry practice, in parallel to modelling approaches, longterm silvicultural options should be experimented. These new experiments will provide to the next generation of foresters very informative results, complementary to those obtained from comparative studies of existing situations.

Local decision should rely on a case by case approach taking into account each particular situation. Following quantitative genetics theory, we expect that in most cases genotypic diversity rather than allelic diversity constrains evolutionary changes. Can we obtain higher rate of change by driving recombination and selection within the current population? Do we need to introduce allochthonous preadapted genotypes to accelerate the emergence and spread of adequate allelic combinations? To address these questions and make a diagnostic, combined genophenotypic approaches in situ are very promising and should be further developed. Molecular tools initially developed for model species now become available for non-model species. Similarly, methodologies and knowledge about the genetic architecture of traits and phenotype construction (e.g. genetic and environmental correlations, age-age correlations) should be generalized to non-model species to help better understanding the gene to trait and gene to fitness mapping.

Box 1-Raising-up complexity (1): the interplay between biotic interactions and evolutionary processes in forest trees

Trees interact with diverse mutualistic and antagonistic insect species. Mutualistic insects may be essential for plant reproduction during pollination, while antagonistic insects may be damageable to plants by consuming and removing plant parts and by selectively feeding on their reproductive tissues (Crawley 1989). The strength of such negative effects depends on the timing, the type and the amount of damage, as well as the stage of the plant's life cycle at which the damage occurs (Marquis 1992). By directly affecting tree reproduction or survival, the demographic and evolutionary consequences of the feeding activities of seed-specialized and tree-killing insect species are thus likely to differ from most forms of herbivory which only result in partial removal of tissues from individual plants (Hulme 1998).

Since seed predation leads to the eradication of individuals in a population, it plays a crucial role in plant population dynamics with possible genetic drift effects when population size is limited and potentially acts as a selective force driving the evolution of particular plant traits such as flowering synchrony, flowering phenology, inflorescence characteristics, flower size, flower longevity and mast seeding (Janzen 1971; Brody 1997; Fenner et al. 2002; Cariveau et al. 2004; Rose et al. 2005; Strauss and Whittall 2006). Many tree species suffer from large seed losses due to predispersal seed predation, which can have significant effects on recruitment and plant population growth rate (Maron and Crone 2006; Kolb et al. 2007). However, the effect of such parasites on the longterm fitness of their host plant appears controversial (Crawley 1989; Horvitz and Schemske 2002), mainly due to the lack of data addressing this issue, especially on perennial plants. There is still a crucial need for studies examining the genetic consequences of massive seed losses within a host tree population, especially in a context in which pre-dispersal seed predation shows significant variation between trees. Indeed, seed loss due to seed-specialized chalcid wasps may vary from less than 1 to $100 \%$ between trees (Roques 1981; Rappaport et al. 1993). At the tree population level, this raises the question of how such local variation in pre-dispersal seed predation may increase or, reversely, decrease the variance of effective seed set among trees, which influences the effective population size.

Evidence of insects directly acting as selective agents on forest trees is still lacking in the literature. Despite the extremely high tree mortality rates recorded during population outbreaks of the bark beetle Dendroctonus ponderosae Hopkins, many trees escape or survive bark beetle attacks, regardless of their vigour, age and/or size (Ott et al. 2011). Little is known about the heritability of tree traits involved in survival to bark beetle attacks such as resin acids (Baradat et al. 1978) and resin flow, viscosity and rate of crystallization (Nebeker et 
al. 1992), in the exception of monoterpene production, which has been shown to be under strong genetic control (Ott et al. 2011).

Understanding how abiotic and biotic disturbances and tree dynamics are interdependent is also crucial for predicting the overall impact of parasitism on tree evolution. Indeed, severe abiotic changes such as droughts and/or heat waves may affect trees and parasites, as well as their interactions (Jactel et al. 2012). Successive drought episodes can affect directly tree survival (Allen et al. 2010), or indirectly when higher temperatures and lower tree resistance trigger severe forest insect outbreaks (OFEFP 2005; Netherer and Schopf 2010; DurandGillmann et al. 2012). The interdependence between climate, biotic factors and tree dynamics remains complex to predict. Drought induced changes in tree nutritional quality (water, carbohydrates and nitrogen contents) or in tree defence mechanisms can limit the development and the damages of parasites (Rouault et al. 2006; Jactel et al. 2012; Forkner et al. 2004). Extreme droughts may even be directly involved in the collapse of herbivorous populations at wide scales (Yarnes and Boecklen 2005). But drought can also affect negatively tree physiology and decrease the effectiveness of tree resistance mechanisms to pathogens and parasites (McIntyre et al. 1996).

Fire ecology provides interesting additional examples of the complexity of integrating interdependencies between trees, biotic and abiotic factors. Bark beetle outbreaks and forest fires have indeed jointly increased in extent and severity during the last decades, raising concerns about their possible interactions (Parker et al. 2006; Simard et al. 2011). Bark beetle outbreaks may increase the probability and intensity of active crown fire because they create great quantities of dead and ladder fuels (Brown 1975; McCullough et al. 1998). However, Simard et al. (2011) suggest that active crown fire are less probable in the short-term after outbreaks due to insectdriven stand thinning, while the probability of passive crown fire does not change in the short term but greatly increases in the decades following an outbreak. Thus, bark beetles are likely to indirectly affect non-attacked trees through subsequent enhanced fire risks. This clearly illustrates the critical need to integrate the possible interplay between the abiotic environment, biotic interactions and trees dynamics when designing forest management strategies.

Box 2-Raising-up complexity (2): evolution and silviculture in a highly spatially heterogeneous environment

In trees, the selection process is complex due to the long life-cycle and the high within-stand spatial environmental heterogeneity. Firstly, for long-lived and sessile organisms, different selection pressures may occur successively from the juvenile stage to the adult stage, e.g. selection for competing ability in a young dense regeneration vs. selection for stress resistance in the adult stage. Secondly, in heterogeneous environment, the phenotypic correlation between parents and offspring do not only depend on genetic control of the phenotype but also on the difference in environmental effects between the parents' and offsprings' sites. Finally, the environmental heterogeneity induces spatial variation in selection pressure, eventually leading to different selection pressure between parents and offsprings. Thus, evolution-oriented forestry should take environmental heterogeneity into account.

As a general objective, evolution-oriented silviculture should aim at favouring the mating success of the best growing trees located in the patches where the highest desired selection pressure occurs. In homogeneous conditions where the selection pressure is uniform, this objective is directly achieved by classical selective thinning. In heterogeneous conditions, this objective could be achieved if enough trees are selected for seeding within each patch where high selective pressure occurs, even though these trees may have lower growth than neighbours growing in more favourable conditions.

In such context, assessing and mapping the environmental heterogeneity among patches is essential to avoid confusion between microenvironmental and genetic effects on the performance of the trees. It is crucial not only to assess the individual performance but also the patch conditions with synthetic indicators, easy to use and independent of the competition, such as site index, species composition of vegetation etc. Local variations of site index can be assessed through spatial patterns of tree height; therefore, it would be easier to identify and mark very early the 'good' phenotypes in highly selective areas, before a substantial reduction in number of trees happens due to other criteria.

Genetic improvement of the whole population will occur if these highly selected trees effectively contribute to the regeneration at stand level. If pollen or seed dispersal limits their effective contribution, considering here fecundity as included into the global dispersal process, it might be necessary to assist natural regeneration by local seed transfer from low to high selection patches within the stand.

Acknowledgments We particularly thank two anonymous reviewers and the editor for their relevant and useful comments on a previous version of the manuscript. The opinions expressed here benefitted from background experimental and modelling research funded by the EVOLTREE network of excellence (www.evoltree.eu), the ERA-Net Biodiversa LINKTREE project, the FRB VARIADAPT project, the ANR MACBI project, the Agropolis Foundation BIOFIS project as well as Région Provence Alpes Côte d'Azur and Département Santé des Forêts.

Open Access This article is distributed under the terms of the Creative Commons Attribution License which permits any use, distribution, and reproduction in any medium, provided the original author(s) and the source are credited.

\section{References}

Aguilar R, Quesada M, Ashworth L, Herrerias-Diego Y, Lobo J (2008) Genetic consequences of habitat fragmentation in plant populations: susceptible signals in plant traits and methodological approaches. Mol Ecol 17:5177-5188

Aitken SN, Yeaman S, Holliday JA, Wang T (2008) Adaptation, migration or extirpation: climate change outcomes for tree populations. Evol Appl 1:95-111

Alberto F, Aitken S, Alia A, Gonzáles-Martinez S, Hanninen H, Kremer A, Lefèvre F, Lenormand T, Yeaman S, Whetten R, Savolainen O (2013) Evolutionary response to climate changeevidence from tree populations. Global Change Biol (in press)

Allen CD, Macalady AK, Chenchouni H, Bachelet D, McDowell N, Vennetier M, Kitzberger T, Rigling A, Breshears D, Hogg EH(Ted), Gonzalez P, Fensham R, Zhang Z, Castro J, Demidova N, Lim JH, Allard G, Running SW, Semerci A, Cobb N (2010) A global overview of drought and heat-induced tree mortality reveals emerging climate change risks for forests. For Ecol Manag 259:660-684

Amm A, Pichot C, Dreyfus P, Davi H, Fady B (2012) Improving the estimation of landscape scale seed dispersal by integrating seedling recruitment. Ann For Sci 69:845-856

Aravanopoulos FA (2011) Genetic monitoring in natural perennial plant populations. Botany $89: 75-81$ 
Ashley M (2010) Plant parentage, pollination, and dispersal: how DNA microsatellites have altered the landscape. Crit Rev Plant Sci 29:148-161

Ayari A, Zubizarreta-Gerendiain A, Tome M, Tome J, Garchi S, Henchi B (2012) Stand, tree and crown variables affecting cone crop and seed yield of Aleppo pine forests in different bioclimatic regions of Tunisia. Forest Syst 21:128-140

Baradat P, Marpeau A, Bernard-Dagan C (1978) Variation of terpenes within and between populations of maritime pine. In: Rudin D (ed) Biochemical genetics of forest trees. Swedish University of Agricultural Sciences, Umea

Bontemps A (2012) Potentiel évolutif d'une population de hêtre commun sur le Mont Ventoux. Ph.D. dissertation, University Paul Cézanne, Aix-Marseille III, Aix en Provence

Bossdorf O, Richards CL, Pigliucci M (2008) Epigenetics for ecologists. Ecol Lett 11:106-115

Bouffier L, Charlot C, Raffin A, Rozenberg P, Kremer A (2008) Can wood density be efficiently selected at early stage in maritime pine (Pinus pinaster Ait.)? Ann For Sci 65:106p2-106p8

Bradshaw AD (1991) Genostasis and the limits to evolution. Philos T R Soc B 333:289-305

Brody AK (1997) Effects of pollinators, herbivores, and seed predators on flowering phenology. Ecology 78:1624-1631

Brown JK (1975) Fire cycles and community dynamics in lodgepole pine forests. In: Baumgartner DM (ed) Symposium Proceedings: Management of lodgepole pine ecosystems. Washington State University Cooperative Extension Service, Pullman, pp 430-456

Brown A, Young A, Burdon J, Christidis L, Clarke G, Coates D, Sherwin W (1997) Genetic indicators for state of the environment reporting, Australia: State of the Environment Technical Paper Series (Environmental indicators). Department of the Environment, Sport and Territories, Canberra

Buchert GP, Rajora OP, Hood JV, Dancik BP (1997) Effects of harvesting on genetic diversity in old-growth eastern white pine in Ontario, Canada. Conserv Biol 11:747-758

Burczyk J, Adams WT, Moran GF, Griffins AR (2002) Complex patterns of mating revealed in a Eucalyptus regnans seed orchard using allozyme markers and the neighbourhood model. Mol Ecol 11:2379-2391

Burczyk J, Adams WT, Birkes DS, Chybicki IJ (2006) Using genetic markers to directly estimate gene flow and reproductive success parameters in plants on the basis of naturally regenerated seedlings. Genetics 173:363-372

Burke KL (2011) The effects of logging and disease on American chestnut. For Ecol Manag 261:1027-1033

Cariveau D, Rebecca EI, Brody AK, Garcia-Mayeya LS, Ohe A (2004) Direct and indirect effects of pollinators and seed predators to selection on plant and floral traits. Oikos 104:15-26

Carter AJR, Hermisson J, Hansen TF (2005) The role of epistatic gene interactions in the response to selection and the evolution of evolvability. Theor Popul Biol 68:179-196

Charmantier A, Garant D (2005) Environmental quality and evolutionary potential: lessons from wild populations. P Roy Soc B - Biol Sci 272:1415-1425

Chevin L-M, Collins S, Lefèvre F (2012) Phenotypic plasticity and evolutionary demographic responses to climate change: taking theory out to the field. Funct Ecol. doi:10.1111/j.13652435.2012.02043.x

Chevin LM, Lande R (2011) Adaptation to marginal habitats by evolution of increased phenotypic plasticity. J Evolution Biol 24:1462-1476

Chevin L-M, Lande R, Mace GM (2010) Adaptation, plasticity, and extinction in a changing environment: towards a predictive theory. PLoS Biology 8:e1000357

Couvet D, Ronfort J (1994) Mutation load depending on variance in reproductive success and mating system. In: Loeschcke V, Tomiuk J,
Jain SK (eds) Conservation genetics. Birkhauser, Basel, pp $55-68$

Crawley MJ (1989) Insect herbivores and plant population dynamics. Annu Rev Entomol 34:531-564

Dounavi K, Steiner W, Maurer W (2002) Effects of different silvicultural treatments on the genetic structure of European beech populations (Fagus sylvatica L.). Manag For Ecosyst 4:81-90

Durand-Gillmann M, Cailleret M, Boivin T, Nageleisen LM, Davi H (2012) Individual vulnerability of Silver fir (Abies alba Mill.) to parasitism by two contrasting biotic agents: mistletoe (Viscum album L. ssp. abietis) and bark beetles (Coleoptera: Curculionidae: Scolytinae) during a decline process. Ann For Sci. doi:10.1007/ s13595-012-0251-y

Eckert AJ, Bower AD, Gonzalez-Martinez SC, Wegrzyn J, Coop G, Neale DB (2010) Back to nature: ecological genomics of loblolly pine (Pinus taeda, Pinaceae). Mol Ecol 19:3789-3805

El-Kassaby YA, Benowicz A (2000) Effects of commercial thinning on genetic, plant species and structural diversity in second growth Douglas-fir (Pseudotsuga menziesii (Mirb.) Franco) stands. For Genet 7:193-203

Endler JA (1986) Natural selection in the wild. Monographs in population biology 21. Princeton University Press, Princeton

Falconer DS (1960) Introduction to quantitative genetics. Oliver and Boyd, Edinburgh

Fenner M, Cresswell JE, Hurley RA, Baldwin T (2002) Relationship between capitulum size and predispersal seed predation by insect larvae in common Asteraceae. Oecologia 130:72-77

Fernandez-M JF, Sork VL (2005) Mating patterns of a subdivided population of the Andean oak (Quercus humboldtii Bonpl., Fagaceae). J Hered 96:635-643

Forkner RE, Marquis RJ, Lill JT (2004) Feeny revisited: condensed tannins as anti-herbivore defences in leaf-chewing. Herbivore communities of Quercus. Ecol Entomol 29:174-187

Forrester DI, Collopy JJ, Beadle CL, Warren CR, Baker TG (2012) Effect of thinning, pruning and nitrogen fertiliser application on transpiration, photosynthesis and water-use efficiency in a young Eucalyptus nitens plantation. For Ecol Manag 266:286-300

Futuyma DJ (2010) Evolutionary constraint and ecological consequences. Evolution 64:1865-1884

García C, Arroyo JM, Godoy JA, Jordano P (2005) Mating patterns, pollen dispersal, and the ecological maternal neighbourhood in a Prunus mahaleb L. population. Mol Ecol 14:1821-1830

García C, Jordano P, Arroyo JM, Godoy JA (2009) Maternal genetic correlations in the seed rain: effects of frugivore activity in heterogeneous landscapes. J Ecol 97:1424-1435

Gilpin ME, Soule ME (1986) Minimum viable populations: processes of species extinction. In: Soule ME (ed) Conservation biology: the science of scarcity and diversity. Sinauer Associates, Sunderland, pp 19-34

Gingerich PD (2009) Rates of evolution. Annu Rev Ecol Evol S 40:657-675

Gomulkiewicz R, Holt RD (1995) When does evolution by natural selection prevent extinction? Evolution 49:201-207

Goodell K, Elam DE, Nason JD, Ellstrand NC (1997) Gene flow among small populations of a self-incompatible plant: an interaction between demography and genetics. Am J Bot 84:13621371

Grivet D, Sebastiani F, Alía R, Bataillon T, Torre S, Zabal-Aguirre M, Vendramin GG, González-Martínez SC (2011) Molecular footprints of local adaptation in two Mediterranean conifers. Mol Biol Evol 28:101-116

Gwaze DP, Bridgewater FE, Byram TD, Woolliams JA, Williams CG (2000) Predicting age-age correlations in tree-breeding programs: a case study in Pinus taeda L. Theor Appl Genet 100:199-206

Hannrup B, Ekberg (1998) Age-age correlations for tracheid length and wood density in Pinus sylvestris. Can J For Res 28:1373-1379 
Hansen MM, Olivieri I, Waller DM, Nielsen EE, the GeM Working Group (2012) Monitoring adaptive genetic responses to environmental change. Mol Ecol 21:1311-1329

Hardy O, Gonzales-Martinez SC, Colas B, Fréville H, Mignot A, Olivieri I (2004) Fine-scale genetic structure and gene dispersal in Centaurea corymbosa (Asteraceae). II. Correlated paternity within and among sibships. Genetics 168:1601-1614

Hoffmann AA, Sgrò CM (2011) Climate change and evolutionary adaptation. Nature 470:479-485

Holliday JA, Ritland K, Aitken SN (2010) Widespread, ecologically relevant genetic markers developed from association mapping of climate-related traits in Sitka spruce (Picea sitchensis). New Phytol 188:501-514

Horvitz CC, Schemske DW (2002) Effects of plant size, leaf herbivory, local competition and fruit production on survival, growth and future reproduction of a neotropical herb. J Ecol 90:279-290

Hulme PE (1998) Post-dispersal seed predation: consequences for plant demography and evolution. Perspect Plant Ecol 1:32-46

Hussendörfer E, Konnert M (2000) Impact of forest management on genetic variation of Silver fir and European beech populations. For Landsc Res 75:187-204

IPCC (2007) Climate change 2007: AR4 synthesis report. An assessment of the Intergovernmental Panel on Climate Change, adopted at IPCC Plenary XXVII, Valencia, Spain, 12-17/11/2007

Jactel H, Petit RJ, Desprez-Loustau M-L, Delzon S, Piou D, Battisti A, Koricheva J (2012) Drought effects on damage by forest insects and pathogens: a meta-analysis. Global Change Biol 195:267-276

Janzen DH (1971) Seed predation by animals. Annu Rev Ecol S 2:465-492

Kircher M, Kelso J (2010) High-throughput DNA sequencing? Concepts and limitations. BioEssays 32:524-536

Klein EK, Carpentier FH, Oddou-Muratorio S (2011) Estimating the variance of male fecundity from genotypes of progeny arrays: evaluation of the Bayesian forward approach. Methods Ecol Evol 2:349-361

Klein EK, Lavigne C, Gouyon PH (2006) Mixing of propagules from discrete sources at long distance: comparing a dispersal tail to an exponential. BMC Ecol 6:3

Kolb A, Ehrlén J, Eriksson O (2007) Ecological and evolutionary consequences of spatial and temporal variation in pre-dispersal seed predation. Perspect Plant Ecol 9:79-100

Konnert M, Hussendörfer E (2001) Genetic variation of silver fir (Abies alba) in unevenaged forests (Plenter forest) in comparison with evenaged forests (Altersklassenwald). Forest Sci 70:307-320

Koski V, Skrøppa T, Paule L, Wolf H, Turok J (1997) Technical guidelines for genetic conservation of Norway spruce (Picea abies (L.) Karst.). International Plant Genetic Resources Institute, Rome

Kramer K, Buiteveld J, Forstreuter M, Geburek T, Leonardi S, Menozzi P, Povillon F, Schelhaas MJ, Teissier du Cros E, Vendramin GG, van der Werf DC (2008) Bridging the gap between ecophysiological and genetic knowledge to assess the adaptive potential of European beech. Ecol Model 216:333353

Kremer A, Le Corre V (2012) Decoupling of differentiation between traits and their underlying genes in response to divergent selection. Heredity 108:375-385

Kremer A, Ronce O, Robledo-Arnuncio JJ, Guillaume F, Bohrer G, Nathan R, Bridle JR, Gomulkiewicz R, Klein EK, Ritland K, Kuparinen A, Gerber S, Schueler S (2012) Long-distance gene flow and adaptation of forest trees to rapid climate change. Ecol Lett 15:378-392

Krouchi F, Derridj A, Lefèvre F (2004) Year and tree effect on reproductive organisation of Cedrus atlantica in a natural forest. For Ecol Manag 197:181-189

Kuparinen A, Savolainen O, Schurr FM (2010) Increased mortality can promote evolutionary adaptation of forest trees to climate change. For Ecol Manag 259:1003-1008
Lande R (2009) Adaptation to an extraordinary environment by evolution of phenotypic plasticity and genetic assimilation. J Evolution Biol 22:1435-1446

Lande R, Arnold SJ (1983) The measurement of selection on correlated characters. Evolution 37:1210-1226

Lauber U, Rotach P, Hussendörfer E (1997) The influence of silvicultural interventions on the genetic structure of a young beech stand (Fagus sylvatica L.). Schweiz Z Forstwes 148:847-862

Lefèvre F (2004) Human impacts on forest genetic resources in the temperate zone: an updated review. For Ecol Manag 197:257271

Lefèvre F, Kajba D (2001) Indicators for monitoring genetic diversity. In: Lefèvre F, Barsoum N, Heinze B, Kajba D, Rotach P, de Vries $\mathrm{S}$, Turok J (eds) In situ conservation of Populus nigra. International Plant Genetic Resources Institute, Rome, pp 36-46

Legay M, Mortier F (2005) La forêt face au changement climatique: adapter la gestion forestière-Prise en compte dans les documents d'orientation de la gestion forestière. Synthèse de l'atelier ONF/ INRA du 20 octobre 2005. Office National des Forêts, Paris. Les Dossiers Forestiers $n^{\circ} 16$

Le Rouzic A, Siegel PB, Carlborg O (2007) Phenotypic evolution from genetic polymorphisms in a radial network architecture. BMC Biol 5:50. doi:10.1186/1741-7007-5-50

Maron JL, Crone E (2006) Herbivory: effects on plant abundance, distribution and population growth. P Roy Soc B 273:2575-2584

Marquis RJ (1992) The selective impact of herbivores. In: Fritz RS, Simms EL (eds) Plant resistance to herbivores and pathogens. University of Chicago Press, Chicago, pp 301-325

Matheson AC, Wu HX, Spencer DJ, Raymond CA, Griffin AR (2002) Inbreeding in Pinus radiata III. The effect of inbreeding on age-age correlation and early selection efficiency. Silvae Genet 51:115122

McCullough DG, Werner RA, Neumann D (1998) Fire and insects in northern and boreal ecosystems of North America. Annu Rev Entomol 43:107-127

McDonald SE, Thomas BR, Cherniawsky DM, Purdy BG (2001) Managing genetic resources of lodgepole pine in west-central Alberta: patterns of isozyme variation in natural populations and effects of forest management. For Ecol Manag 152:45-58

McIntyre GA, Jacobi WR, Ramaley AW (1996) Factors affecting Cytospora canker occurrence on aspen. J Arboric 22:229-233

Metzker ML (2009) Sequencing technologies - the next generation. Nat Rev Genet 11:31-46

Milleron M, Lopez de Heredia U, Lorenzo Z, Perea R, Dounavi A, Alonso J, Gil L, Nanos N (2012) Effect of canopy closure on pollen dispersal in a wind-pollinated species (Fagus sylvatica L.). Plant Ecol 213:1715-1728

Mimura M, Aitken SN (2007) Adaptive gradients and isolation-bydistance with postglacial migration in Picea sitchensis. Heredity 99:224-232

Misson L, Nicault A, Guiot J (2003) Effects of different thinning intensities on drought response in Norway spruce (Picea abies (L.) Karst.). For Ecol Manage 183:47-60

Moose SP, Dudley JW, Rocheford TR (2004) Maize selection passes the century mark: a unique resource for 21 st century genomics. Trends Plant Sci 9:358-364

Mosseler A, Major JE, Rajora OP (2003) Old-growth red spruce forests as reservoirs of genetic diversity and reproductive fitness. Theor Appl Genet 106:151-161

Namkoong G, Boyle T, Gregorius HR, Joly H, Savolainen O, Ratnam W, Young A (1996) Testing criteria and indicators for assessing the sustainability of forest management: genetic criteria and indicators. Center for International Forestry Research CIFOR, Bogor. Working Paper $\mathrm{N}^{\circ} 10$

Neale D, Savolainen O (2004) Association genetics of complex traits in conifers. Trends Plant Sci 9:325-330 
Nebeker TE, Hodges JD, Blanche CA, Honea CR, Tisdale RA (1992) Variation in the constitutive defensive system of Loblolly pine in relation to bark beetle attack. Forest Sci 38:457-466

Netherer S, Schopf A (2010) Potential effects of climate change on insect herbivores-general aspects and a specific example (Pine processionary moth, Thaumetopoea pityocampa). For Ecol Manag 259:831-838

Nilsson JE (1995) Genetic variation in the natural pollen cloud of Pinus sylvestris: a study based on progeny testing. Scand J Forest Res 10:140-148

Oddou-Muratorio S, Demesure-Musch B, Pélissier R, Gouyon PH (2004) Impacts of gene flow and logging history on the local genetic structure of a scattered tree species, Sorbus torminalis L. Crantz. Mol Ecol 13:3689-3702

Oddou-Muratorio S, Klein EK, Austerlitz F (2005) Pollen flow in the wildservice tree, Sorbus torminalis (L.) Crantz. II. Pollen dispersal and heterogeneity in mating success inferred from parentoffspring analysis. Mol Ecol 14:4441-4452

OFEFP, Rapport forestier (2005) Faits et chiff res sur l'état de la forêt suisse. Office fédéral de l'environnement, des forêts et du paysage, Berne

Osório J, Pereira JS (1994) Genotypic differences in water-use efficiency and ${ }^{13} \mathrm{C}$ discrimination in Eucalyptus globulus. Tree Physiol 14:871-882

Ott DS, Yanchuk AD, Huber DPW, Wallin KF (2011) Genetic variation of lodgepole pine, Pinus contorta var. latifolia, chemical and physical defenses that affect mountain pine beetle, Dendroctonus ponderosae, attack and tree mortality. J Chem Ecol 37:1002-1012

Parker TJ, Clancy KM, Mathiasen RL (2006) Interactions among fire, insects and pathogens in coniferous forests of the interior western United States and Canada. Agri For Entomol 8:167-189

Pease CM, Lande R, Bull JJ (1989) A model of population growth, dispersal and evolution in a changing environment. Ecology 70:1657-1664

Petit RJ, Hampe A (2006) Some evolutionary consequences of being a tree. Annu Rev Ecol Evol S 37:187-214

Pichot C, Bastien C, Courbet F, Demesure-Musch B, Dreyfus P, Fady B, Frascaria-Lacoste N, Gerber S, Lefèvre F, Morand-Prieur ME, Oddou S, Teissier du Cros E, Valadon A (2006). Déterminants et conséquences de la qualité génétique des graines et semis lors de la phase initiale de régénération naturelle des peuplements forestiers. Les Actes du BRG n ${ }^{\circ} 6$, Burreau des Ressources Génétiques, Paris, pp 277-297

Pigliucci M (2008) Is evolvability evolvable? Nat Rev Genet 9:75-82

Prat D, Faivre-Rampant P, Prado E (2006) Analyse du génome et gestion des ressources génétiques forestières. INRA ed Quae, Paris

Rajora OP, Rahman MH, Buchert GP, Dancik BP (2000) Microsatellite DNA analysis of genetic effects of harvesting in old-growth eastern white pine (Pinus strobus) in Ontario, Canada. Mol Ecol 9:339-348

Ramirez-Valiente JA, Valladares F, Huertas AD, Granados S, Aranda I (2011) Factors affecting cork oak growth under dry conditions: local adaptation and contrasting additive genetic variance within populations. Tree Genet Genomes 7:285-295

Rappaport NG, Mori S, Roques A (1993) Estimating effect of Megastigmus spermotrophus (Hymenoptera: Torymidae) on Douglas-fir seed production: the new paradigm. J Econ Entomol $86: 845-849$

Rehfeldt GE, Wykoff WR, Ying CC (2001) Physiologic plasticity, evolution, and impacts of a changing climate on. Clim Chang 50:355-376

Restoux G, Silva ED, Sagnard F, Torre F, Klein E, Fady B (2008) Life at the margin: the mating system of Mediterranean conifers. Web Ecology 8:94-102

Ritland K (1996) A marker-based method for inferences about quantitative inheritance in natural population. Evolution 50:1062-1073
Robledo-Arnuncio JJ (2011) Wind pollination over mesoscale distances: an investigation with Scots pine. New Phytol 190:222-233

Robledo-Arnuncio JJ, Alía R, Gil L (2004) Increased selfing and correlated paternity in a small population of a predominantly outcrossing conifer, Pinus sylvestris. Mol Ecol 13:2567-2577

Rockman MV (2012) The QTN program and the alleles that matter for evolution: all that's gold does not glitter. Evolution 66:1-17

Roques A (1981) Biologie et répartition de Megastigmus spermotrophus Wachtl. (Hymenoptera: Chalcidoidea Torymidae) et des autres insectes liés aux cônes dans les peuplements forestiers et vergers à graines français de sapin de Douglas Pseudotsuga menziesii [Mirb.] Franco. Acta Oecol 2:161-180

Rose KE, Louda SM, Rees M (2005) Demographic and evolutionary impacts of native and invasive insect herbivores on Cirsium canescens. Ecology 86:453-465

Rouault G, Candau JN, Lieutier F, Nageleisen L-M, Martin JC, Warzée $\mathrm{N}$ (2006) Effects of drought and heat on forest insect populations in relation to the 2003 drought in Western Europe. Ann For Sci 63:613-624

Sáenz-Romero C, Guzmán-Reyna R, Rehfeldt G (2006) Altitudinal genetic variation among Pinus oocarpa populations in Michoacan, Mexico. Implications for seed zoning, conservation, tree breeding and global warming. For Ecol Manag 229:340-350

Sagnard F, Oddou-Muratorio S, Pichot C, Vendramin GG, Fady B (2011) Effects of seed dispersal, adult tree and seedling density on the spatial genetic structure of regeneration at fine temporal and spatial scales. Tree Genet Genomes 7:37-48

Savolainen O, Pyhäjärvi T, Knürr T (2007) Gene flow and local adaptation in trees. Annu Rev Ecol Evol S 38:595-619

Schleuning M, Farwig N, Peters MK, Bergsdorf T, Bleher B, Brandl R, Dalitz H, Fischer G, Freund W, Gikungu MW, Hagen M, Garcia FH, Kagezi GH, Kaib M, Kraemer M, Lung T, Naumann CM, Schaab G, Templin M, Uster D, Wagele JW, Bohning-Gaese K (2011) Forest fragmentation and selective logging have inconsistent effects on multiple animal-mediated ecosystem processes in a tropical forest. PLoS One 6:e27785

Schoen D, Brown HD (1991) Intraspecific variation in population gene diversity and effective population size correlates with the mating system in plants. P Natl Acad Sci USA 88:4494-4497

Silvertown JW (1980) The evolutionary ecology of mast seeding in trees. Biol J Linn Soc 14:235-250

Simard M, Romme WH, Griffin JM, Turner MG (2011) Do mountain pine beetle outbreaks change the probability of active crown fire in lodgepole pine forests? Ecol Monogr 81:3-24

Skrøppa T, Tollefsrud M, Sperisen C, Johnsen Ø (2010) Rapid change in adaptive performance from one generation to the next in Picea abies - central European trees in a Nordic environment. Tree Genet Genomes 6:93-99

Smouse P, Dryer RJ, Westfall RD, Sork VL (2001) Two-generation analysis of pollen flow across a landscape. I. Male gamete heterogeneity among females. Evolution 55:260-271

Smouse P, Sork VL (2004) Measuring pollen flow in forest trees: an exposition of alternative approaches. For Ecol Manag 197:21-38

St Clair JB, Howe GT (2007) Genetic maladaptation of coastal Douglas-fir seedlings to future climates. Global Change Biol 13:1441-1454

Strauss SY, Whittall JB (2006) Non-pollinator agents of selection on floral traits. In: Harder LD, Barrett SCH (eds) Ecology and evolution of flowers. Oxford University Press, Oxford, pp 120-138

Tene A, Tobin B, Dyckmans J, Ray D, Black K, Nieuwenhuis M (2011) Assessment of tree response to drought: validation of a methodology to identify and test proxies for monitoring past environmental changes in trees. Tree Physiol 31:309-322

Thiebaut B, Comps B, Leroux A (1992) Relation hauteur-génotype dans une régénération naturelle de hêtre (Fagus sylvatica) équienne et agée de 18 ans. Ann Sci For 49:321-335 
Walsh B, Blows MW (2009) Abundant genetic variation+strong selection=multivariate genetic constraints: a geometric view of adaptation. Annu Rev Ecol Evol S 40:41-59

Wright S (1931) Evolution in Mendelian populations. Genetics 16:97158

Wu HX, Powell MB, Yang JL, Ivkovic M, McRae TA (2007) Efficiency of early selection for rotation-aged wood quality traits in radiata pine. Ann For Sci 64:1-9

Yan H, Bi HQ, Li R, Eldridge R, Wu Z, Li Y, Simpson J (2006) Assessing climatic suitability of Pinus radiata (D. Don) for summer rainfall environment of southwest China. For Ecol Manag 234:199208

Yarnes C, Boecklen WJ (2005) Abiotic factors promote plant heterogeneity and influence herbivore performance and mortality in Gambel's Oak (Quercus gambelii, Nutt.). Entomol Exp Appl 114:87-95

Yousefpour R, Jacobsen JB, Thorsen BJ, Meilby H, Hanewinkel M, Oehler K (2012) A review of decision-making approaches to handle uncertainty and risk in adaptive forest management under climate change. Ann For Sci 69:1-15 